\title{
Acceptability Testing of Radioluminescent Lights for VFR-Night Air Taxi Operations
}

G. A. Jensen

January 1985

Work Supported by

the U.S. Department of Energy

under Contract DE-AC06-76RLO 1830,

the U.S. Department of Defense, and the State of Alaska

Pacific Northwest Laboratory

Operated for the U.S. Department of Energy

by Battelle Memorial Institute 
DISCLAIMER

This report was prepared as an account of work sponsored by an agency of the United States Government. Neither the United States Government nor any agency thereof, nor any of their employees, makes any warranty, express or implied, or assumes any legal liability or responsibility for the accuracy, completeness, or usefulness of any information, apparatus, product, or process disclosed, or represents that its use would not infringe privately owned rights. Reference herein to any specific commercial product, process, or service by trade name, trademark, manufacturer, or otherwise, does not necessarily constitute or imply its endorsement, recommendation, or favoring by the United States Government or any agency thereof. The views and opinions of authors expressed herein do not necessarily state or reflect those of the United States Government or any agency thereof.

\author{
PACIFIC NORTHWEST LABORATORY \\ operated by \\ BATTELLE \\ for the \\ UNITED STATES DEPARTMENT OF ENERGY \\ under Contract DE-AC06-76RLO 1830
}

\begin{tabular}{|c|c|}
\hline \multicolumn{2}{|c|}{ Printed in the United States of America } \\
\hline \multicolumn{2}{|c|}{ Available from } \\
\hline \multirow{2}{*}{\multicolumn{2}{|c|}{$\begin{array}{l}\text { National Technical Information Service } \\
\text { United States Department of Commerce }\end{array}$}} \\
\hline & \\
\hline \multicolumn{2}{|c|}{ Springfield, Virginia 22161} \\
\hline \multirow{2}{*}{\multicolumn{2}{|c|}{$\begin{array}{l}\text { NTIS Price Codes } \\
\text { Microfiche } A 01\end{array}$}} \\
\hline & \\
\hline \multicolumn{2}{|c|}{ Printed Copy } \\
\hline & Price \\
\hline Pages & Codes \\
\hline 001.025 & $\wedge 02$ \\
\hline 026.050 & $A 03$ \\
\hline 051.075 & AOA \\
\hline $076-100$ & A0S \\
\hline $101-125$ & $A \infty 6$ \\
\hline $126-150$ & $\wedge 07$ \\
\hline $151-175$ & 100 \\
\hline $776-200$ & $A 09$ \\
\hline $201-225$ & 1010 \\
\hline $226-250$ & A011 \\
\hline 251.275 & $\mathrm{~A} 012$ \\
\hline $276-300$ & $\mathrm{~A}_{013}$ \\
\hline
\end{tabular}




\section{ACEEPTABILITY TESTING OF \\ RADIOLUMINESCENT LIGHTS FOR UFR-NMGHT \\ AT THA OPERATIONS}

6. A. Jensen

January 1985

Supported by

the U.5. Department of Eneray

under contract OE-ACOC-76RLo 1830.

the U.S. Department of Defense, and the state of Alaska

Pacific Northwest Laboratory

Richland, Washington 99352 
,

$+$ 


\section{ACKNOWLEDGMENS}

The help and support of the U.S. Department of Energy and the State of Alaska Department of Transportation and Public Facilities have been important in developing civilian applicatons of radioluminescent airport lighting systens. We also wish to express our sincere thanks to the Federal Aviation Adnintstration and the following individuals whose help ensured the success of the work reported here.

Leroy Leonard

Karl Haff

Tom Hardy
Chie of Energy and Bulldings Research, State of Alaska Department of Transportation and Public Faciltities

Program Manager, Radioisotope Development and Applications, Dak Ridge National Laboratory, Dak 政idge, Tennessee

Project Officer, Air Force Engineering and Service Genter, Tyndail Air Force Ease, Florta 


\section{SUMMARY}

Tritium-powered radioluminescent (RL) lights have been under development by the U.S. Department of Energy (DOE) for remote, austere, and tactical air. fleld It thing applications were electrical utility or portable power is unavaliable or difficult to obtain. Because the technology has promise for use in civilian applications and military operations in Alaska and other similar locations, user organizations such as the U.5. Department of Defense (DoD), the state of Alask Department of Transportation and Public Facilities (DOT\&P), and others have funded work to meet their specific objectives. In order to plan and coordinate the needs for the various funding organizations, a technical working group (TWG) has been formed us ing individuals from DoE, noo, clullan sponsors, Oak Ridge National Laboratory (ORN), and Pacific

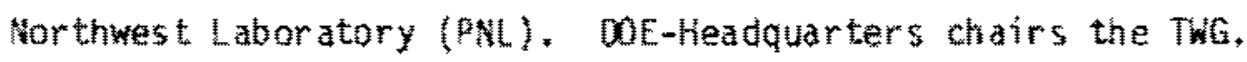

The State of Alask has requested appropr late Federal Aviation Adninistration (FAA) approvals for use of the technology as a safe alternative lighting system to meet the airfield iogting needs of air taxi operations and general aviation in the state. The tests described in this report were performed by PNL for the DOE Deferse Byproducts Production and It llization Program and are a step towards gallining the requited approvals.

The specific purpose of the evaluation was to provide a formal initial evaluation of the Ri runway lighting systeri, which could lead to FAA approva: for use in nighttime aircraft operations under Part 135 of the Faderal Aviation Regulations (FAR). These tests apply only to Part 135 of the FAR, and otmer tests may be reguired to meet other parts of the FAR. The results fron these tests will also aid in developing the lights for military purposes.

Test work was performed during september and early october loga at a selected rura runwa near Rithland, Washington. FAM and ORNL participation in the test was coordinated by State of Alaska and PNL personel. The goals of this flight testing were to:

- Further evaluate human factors and other factors affecting the lights and their use. 
- Evaluate landing procedures for Category A arcraft us ing the lights and suggest modifications in existing procedures that could be used by higher performance aircraft. Most aircraft and pilots using the RL system for civilian aviation will be flying smaller, Category A, lower performance aireraft.

All testing was completed under high visibility (10 miles or greater). visual flight rules (UFR) conditions. More testing may be needed at or near UFR minturums (2- to 3-mile visubility) before full approval for use of the lights is obtained.

Test results are quite favorable. All pilots could identify, maintain contact with, and use the runway from a minimum of 1.5 miles during approach and in preparation for landing. Although full-sop or touch-and-go landings were not pernitted, most plots felt that they would have no difficulty landing to the lights. In addition, pllots reported that they could use the lights for runay alignment from distances greater than 2 miles under very dark clear conditions and between 1.5 and 2 miles under $3 / 8$ to $2 / 3$ moonlight and hazy conditions. Some pilots and observers reported visual contact with the runtay at 3 to 5 miles along the extended rumay centerline and 2 to 2.5 mos hen $90^{\circ}$ from the runway direction. 


\section{CONTENTS}

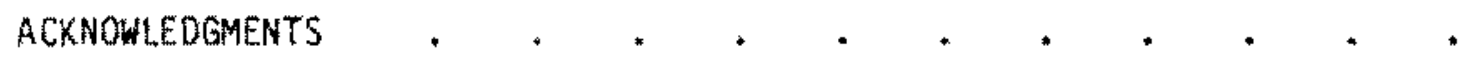

SUMMARY

1.0 IHTRODUCTION

1. PURPOSE AND SCOPE OF WORK

1. 2 REPORT ORGANIZATUON. . . . . . . . *

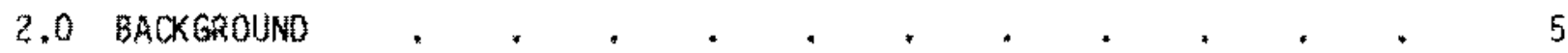

2.) NEED FDR SELF-POWERED LIGHTING . . . . * . 5

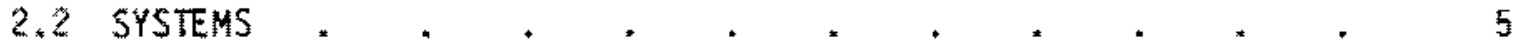

2.3 POSSIELE IMPLEMENTATION STRATEGY * * * . * * 6

3.0 CRITERIA DEVELOPMENT AND TEST IMPLEMENTATION * + . * * 9

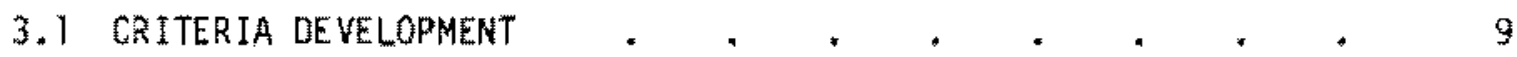

3.2 TEST IMPLEMENTATION . . . . . . . . 13

4.0 TEST RESULTS AND DISCUSSION . . + . . . . . . 19

毒 I TEST RESULTS * * * * * * * * * * 19

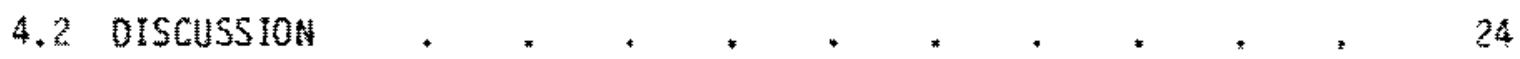

5.0 RECOMMENDATIONS . . . . . . . . . . 27

6.0 REFERENCES . . . . . . . . . . . . . . . . . . 29 


\section{FIGURES}

1 Strobes Used for Evaiuations Near Benton City, Washington . . 14

2 Site of Federal Aviation Administration Test . . . . . . . . 14

3 Flight Test Runway . . . . . . . . . . . . . . . 15

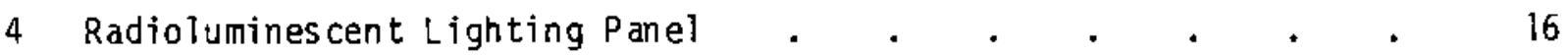

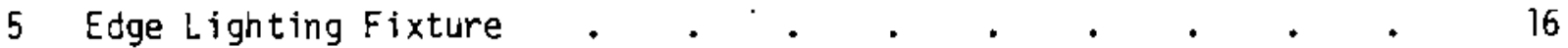

6 Threshold Configuration at East End of Test Runway . . . 17

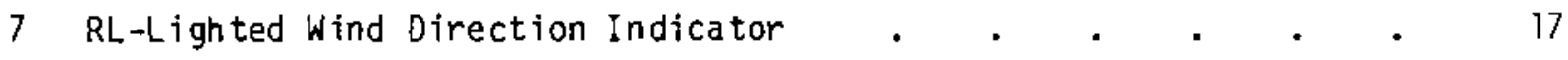

8 Pilot Questionnaire and Data Sheet . . . . . . . . 20

g Possible Visual Glide Slope Indicators . . . . . . . . . 25

TABLES

1 Pilot Concerns or Comments . . . . . . . . . . . 23 
, 


\subsection{INTEOUUCTION}

Tritium-powered radioluminescent (RL) lights have been under development by the U.5. Department of Energy (DOE) for remote, austere, and tactical airfield lighting applications where electrical uttlity or portable power is unavallable or difficult to obtain. Becase the technology has promse for use in clullian applications and military operations in Alaska and other siniTar locations, (1-8) user organizations such as the U.S. Department of Dafense (DoD), the State of Alaska Department of Transportation and Public Facilities (DDT\&PF), and others have funded work to met their specific objectives. In order to $p l$ an and coordinate the needs for the various funding organizations, a technical working group (TWG) has been formed using individuals from DoE, Doo, civilian sponsors, Dak Rige Nationa: Laboratory (orML), (a) and pacific Northwes: Laboratory (PNL), (t) DOE-Headquarters chairs the TWG.

The need for a usble low-cost, self-powered lighting system for rural A lask an runways has been fdentified; $(1,3, \mathrm{~B})$ and results of demonstrations and tests show that RL lighting can meet this need. ( $1-3,8)$ Thus, the Alaska DOT\&PF has requested that the Alask an Region of the Federal Aviation Administration (FAA) approve (b) RL ruway lighting systems for use for nightime aperations in rural Alask ander Parts 91 and 135 of the Federal Aviation Regulations (FAR) * Additionally, similar discusstons were held with FAA Headquarters and FAA Technical Center personnel.

The result was a request to the chairman of the ThG for a test, providing that agreement could be reached between the Alaska DoT\&PF and the FAA on the criterta for the testing. Possible locations were in Alaska and Richland, Washington. Richland was proposed as a possible sute since the work could be performed unter the Dot vefense Byproducts Production and Utillization propram, trained PW personel were awailable, the location was central for all possible participants, the rurat character resemlad Alaska, major airport facllities

(a) ORNL is operated for DOE by Martin Marietta Company. PNL is opmated for DoE by Battelle Memorial Institute.

(b) For information on discussions with or correspondence between the state of Alaska DOTRPF and the FAA, contact the Rlaska DOT\&PF, Facilities Research, Fairbarks, Aiaska. 
were close to known rural runways, there were longer periods of darkness relative to Alaska during the proposed test period, and logistical requirements could to be met.

Thus, at the request of the TWG, a preliminary plan and cost breakdown was submitted in july 1984 to perform flight testing to establish light performance and determine acquisition distances. This information was needed to demonstrate the acceptability of RL lights to FAA flight standards personnel for meeting Part 135 of the FAR for nighttime air taxi landing operations. The work was performed during September 1984 at a selected rural runway near Richland, Washington. FAA participation in the test was coordinated by State of Alaska and PNL. personnel. The authorization for detailed planning was given in September, a final test plan was prepared, and the testing was completed on schedule.

\subsection{PURPOSE AND SCOPE OF WORK}

Although RL lights have been demonstrated for runway lighting and marking applications, regulatory approval by the FAA for use under various parts of the FAR requires specific flight testing and evaluation. (a) Therefore, the purpose of the evaluation was to provide a formal initial evaluation of the RL runway lighting system, which could lead to FAA approval for use in nighttime aircraft operations under Part 135 of the FAR. These tests apply only to Part 135 of the FAR, and other testing may be required to fully meet Part 135 as well as other parts of the FAR. The results from these tests could also aid in developing the lights for military purposes. The goals of this flight testing were to: $(\mathrm{b})$

- Further evaluate human factors and other factors affecting the lights and their use.

- Evaluate landing procedures for Category $A$ aircraft using the Tights and suggest modifications in existing procedures that could be used by higher performance aircraft. Most aircraft and pilots using the RL system for civilian aviation will be flying smaller, Category $A$, lower performance aircraft .

(a) FAA correspondence from W. T. Breanan, Manager, Air Transportation DiviSion, Office of Flight Operations to L. E. Leonard dated July 10, 1984.

(b) Correspondence from L. E. Leonard, State of Alaska, DOT\&PF to T. H. Paprocki, FAA, Atlantic City, New Jersey, dated July 16, 1984. 
Thus, the scope of the effort was to develop a procedure for using a RL runway lighting system and determine the suitability of the lights for providing nighttime visual guidance for approach and landing operations to safely support FAR 135 commercial air taxi operations. Specific activities included:

- Coordinate with the State of Alaska and the FAA to develop a procedure for using the systern.

- Identify suitable runways and select a site for the tests.

- Ensure that the logistical needs of the test were met.

- Coordinate with FAA Technical Center personnel in Atlantic City, New Jersey, to ensure that sufficient subject pilots and aircraft were avaijable for the test and that other test needs were met.

- Report results as appropriate.

\subsection{REPORT ORGANIZATION}

The following sections of the report provide a brief background on Alaskan needs for RL lighting, the criteria development and implementation work, a summary of the results of the effort, and recommendations for future work. RL lighting principles and cost advantages of RL runway lighting are described in detail elsewhere ${ }^{(1-23)}$ and will not be repeated here. An FAA report was prepared $(24)$ and is a particulariy important reference since it includes information tape recorded by those flying in the aircraft that was not supplied to the author who was on the ground for most of the test. 


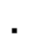

. 


\subsection{BACKGROUND}

Discussions of the need for self-powered lighting systems in the worth and the current strategy for meting rural Alask an airfield lighting needs are provided in this section.

\subsection{NEED FOR SELF - POWERED LIGHTING}

In winter, much of the land and watermased transportation in Alaska (and the Arctic) becones impassable. Thus, for much of the North, air transportation becomes the only alternative to meet the needs for goods and services of the significant but widely scattered population. These pockets of habitation exist for a variety of reasons: native Anerican traditions, resource development and exploration, government agency and military requirements, etc. The separation from the greater economic infrastructure of the nation, the extreme enviromental conditions, and short winter daylight hours at hiph latitudes place several limits and demands on personnel, equipanent, and systems operating, used, and/or installed in Alaska or other northern locations. In addition, anly a small number of existing Alaskan runways are i ighted. Thus, comercial air carriers mus have more aircraft and plots to operate during the short daylight hours, which severely restricts their ablity to provide safe and tinely service. (2) Ground maintenance and operations are affected by the cotd; electrital systems and batter ies fat; and other neans for providing backup airfield lighting in energency and critical situations are improperly used, adding to the problem of providing safe, reliable air service to the rural population. Efficiency and safety could be significantly improved if civilian airfields were equipped whin self powered lights.

\subsection{SYSTEMS}

Currently, there are two types of lighting comonly used to atd commercial night operations in Alaska:

- FAAmapproved medium-intensity runway lighting (MIRL) or high-intensity runway lighting (HIRL) as described in FAA Advisory Circular 
萧 150/5340-24 - These lighting systems include electric incandescent runway edge and thresholi lights, blue taxiway lights, a rotating locator beacon, and a lighted wind direction indicator (wind T).

- flare pots or lanterns for night visual flight rules (VFR) for only nonpassenger-carrying comercial aircraft (Part 91 of the FAR) or under special permission granted a carrier by FAa under Part 135.229 of the FAR if passengers are aboard. This systen consists of flare pots or lanterns spaced at 400-ft interyals along both edges of the runway and some means of comunicating wind direction information to the plot.

MIRL and HIRL systens are specified in detail and $c$ an only be nodified by special waver from the FAA in washington, D.C. These systems are costiy and difficut to wathain and operate in rura Alaska. (1,3,8) The use of flare pots and Ianerns is interpreted more ioosely by the regulators and can be modified within the jurisdiction of a particular region of FAA, such as the Alaska region. There are severe problems related to the use of flare pots or lanterns. These relate to having them correctiy placed along the runway for landing operations, personnel willing to place thern at all in the severe weather or darkness, and other factors, (a) RL runway lighting systens shauld be an attractive alternative for use in the state since they have modest cost and low maintenance and are self-powered arid reliable. (1-4)

\subsection{POS5IBLE IMPLEMENTATION STRATEGY}

A posstble implementation strategy for the RL system use within Alask is: $(1,8)$

- Use of the RL systen would begin at selected presently un lighted rural runways as alternative to fare pots or lantems umder parts 91 and 135 of the FAR. After a period of time during which satisfactory results are show and the system proved its worth in Alaska, users would be expected to seek federal approval for RL systems as substitutes for MIRL sys tems.

(a) Based on personal interviews with air taxi, FAA pilots, and other pilots in Alaska. 
- When the RL system has gained full FAA acceptance, the state would accelerate its installation rate at unlighted airports and begin replacement of particularly troublesome electric systems. As existing electric systems reach the practical limit of their life cycles, the state would make further replacements with RL light systems, working toward eventual standardization of the RL lighting system.

The tests and results described in this report are start to implementing this strategy to ensure safe and reliable runway lighting at rural northern locations. 


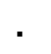




\subsection{CRITERIA DEVELOPMENT ANO TEST IMPLEMENTATION}

Criteria development and test implementation are discussed in the following paragraphs.

\subsection{CRITERIA OE YELOPMENT}

Since RL lighting represents a new technology for aircraft runway lighting and narking, criter la neded to be devaloped for its use so that pllots us ing the system gain the advantages of the system while not compromising safety* Thus, the Alaska DOT\&PF, with the aid of PNL, developed performance criteria based on discussions with the FAA. (a) The results of this effort are surnarlzed as follows:

1* RL lighting systems wll consist of the following components:

* unitized Rl lights (unitized panels, etc.) placed along both sides of the runwy beginning at the threshold and located at a maxirum of 400- ft intervals ending at the opposite threshold

- a spatially separated array of unttized RL lights placed along the left-hand edge of the primary approach end of the runway to provide visual glide slope information

- an electric strobe beacon located a maxitum of 1 mile from the runway; an alternating whte and green color pattern will flash approximately 15 to 20 flashes per min.

2. Performance criteria:

- RL edge lights wlll produce an outline of the runway of sufficient brilliance that a pllot with average visual acuity can positively determine the alrorats orientation relative to the runwa while conducting normal airoraft manetwering whin the airport braftic patern, including manevvering to crosswind, downind, and base legs and circling at a radius and altitude appropriate to the type of air-

(a) Correspondence from L. E. Leonard, State of Alaska, OOTEF to T. H. paprocki, FAA, Atlantic ity, New Jersey, dated July 16, 1984 , 
craft that will be operating on the runway as prescribed in FaAs flight training handbook (AC-61-21A). For aircraft with approach speeds of 90 knots or less, a minimum of 1.3 nautical miles (NM) beyond the perimeter of the landing surface is required. The above will apply under any night VPR conditions in which operations are pernitted under appropriate FARs. In addition, the fllunination shall be sufficient to permit the sane pllot to begin and matntain stabilized rinal approach immetiately upon completion of the base to final turn when following the RL-UFR operational procedure described below (Item 3).

- The Rl visual gitde slope indicator shall be of sufficient brilliance and clarity to provide a plot with average visual acuity a visual indication of the arcraft's adherence to the glide slope appropriate for the terrain (a) (normally $3^{\circ}$ ) beginning not less than 1 statuta flle from the threshold during a stablized fual approach. This requirement shafl be valid for any night vFr condition permitted under the appropriate FARs.

- A locator beacon will be munted so that it is clearly visible within a minimum of 10 miles radius of the airport to an aircrat flying at an altitude of 5000 th above ground level (AcL) during a night VFf condition where the ustollity is 10 statute miles or more.

3. When operating at an arport equipped wh an $\mathrm{RL}$ runwa lighting $\$$ ysten under night VFR conditons, the follawing thatht procedure will be followed:

- The pilot will navigate to the vicinity of the airport by whatever means are at his disposal.

- Upon approaching the vcinity of the atrport, the pilot will attempt to latentify the locator beacon, which wll be distinguishable by alternate white and green flashes. The pilot will fly a course intended to overhead the beacon while initiating a preliminary descent at a rate appropriate to the terrain and intended to a hieve approxinately $300 \mathrm{ft}$ AGL upon arrival at the beacon.

(a) This ray not be possible where montains or sinilar terrain vartations are close to the airport. 
- Upon appraching the beacon, the pilot will identify the runway and its orientation by the Rt edge lights. The pllot will continue to fly to the beacon overheading the airport and manetsering the aircraft to enter the appropriate downwind legla ${ }^{(a)}$ of a normal VFR traffic pat. tern. Continuing dowtind, the pilot will begin to turn base leg at approximately a $45^{\circ}$ angle from the end of the runway. A descent should be in itiated at the beginning of the turn to base combinuing in a norma $Y S R$ traffic pattern and turning to a final approach intended to intersect an extended runway center line at approximately 450 ft AGL and astuming a stablitized approach to a landing with atd of the RL y isual glide slope indicator as required.

- If the pllat is unfamiliar with the airport, he should adjust the procedure described above as follows. The pilot will initiate a prelitinary descent intended to overhead the beacon at an althtude of 1500 to $2000 \mathrm{ft}$ AGL. At this point, the pilot will identify the runway and proceed to enter the normal VFR traffic pattern, circling the airport while descending to approximately $800 \mathrm{ft}$. AGit, entering the appropriate downwind leg, and proceeding as above. (b)

For the test and evaluation, the minimum acceptable criteria for the RL lighting system were modfled from those above as follows:

(a) The appropm late downind leg will be determined by a lighted wind indicator or direct radio comunication with observers on the ground. The pllot is also advised to use the overhead of the airport and the downind leg to look carefully the landing surface in an attempt to ldentify any hazardous osstuthions that are sometimes encountered on remote airports.

(b) The $\mathrm{R}$. lights are of low intensity and not intended to provide positive wisual reference beyond the timits of a normal trafic patern 1.3 miles beyond the perimeter of the landing zone), al though they ma be yisible at ruch greater distances under favorable conditions. The locator beaton is intended to be the only vistia navigational reference outside the norial traffic pattern boundary. Thus, the pllot is advised to always use the system as per the above procedure, noting the positional relationship of the aircraft, beacon, and runway during all operations. It, while maneuvering in the airport vicinity, the pllot is required to operate outside the normal traffic pattern boundary (for example, to accommodate other traffic), the correct procedure requires that an approach to the beacon agatn be initiated, entering the pattern as described above. 
- The RL lighting system must be of sufficient luminescence to provide immediate recognition of the aircraft's orientation with respect to the runway while maneuvering at $1000 \mathrm{ft}$ AGL at all points in the runway traffic pattern within a distance of 1.3 nautical miles of the runway. Once seen, the RL runway and threshold lights must provide this immediate recognition throughout the airport traffic pattern and approach. The mere detection of a light source that would indicate the presence of a runway without recognition of the runway orientation is not acceptable.

- The RL lighting system must be capable of meeting this operational criteria under the following conditions:

a) prevailing visibility of 2 to 3 statute miles

b) clear moonlit night where the contrast between the runway surface and the adjacent area is such that the definition of the runway cannot be determined without the aid of runway edge lights.

- The system must include a low-powered airport identification beacon located within $5000 \mathrm{ft}$ of the runway and of sufficient intensity to permit identification of the runway/airport location at a distance of 10 statute miles in unlimited visibility conditions.

- The system must include an 111 uminated wind direction indicator capable of providing wind direction information to a pilot overflying the runway at pattern altitude.

While the 1.3-knot distance criterion described above has been developed for Category A aircraft, (a) the lighting system could be adapted to larger higher performance aircraft once more experience with the system is available. On the bas is of the above criteria, a test procedure was developed by FAA Technical Center personnel in coordination with PNL and State of Alaska DoT\&PF.

The test procedure consisted of three phases. Each phase was completed twice for a left- and right-landing pattern. In Phase I, the subject pilots were flown to three locations $\mathbf{1 . 3}$ miles away from the runway. At each location, they were told the general location of the runway and the safety pilot asked if they could clearly see the runway and to point to its location.

(a) Category $A$ aircraft are the primary aircraft used by air taxi operations in Alaska. 
In Phase II, the pilots were located at a flight path parallel to the runway centerline (downwind leg) and given control of the aircraft. The safety pilot then directed the subject pilot to complete the approach to the runway and make a low flyover to demonstrate that he had the required alignment and position for landing. In Phase III, the safety pilot flew the aircraft to a location between 4 and 5 miles from the airport. The subject pilot was then given control of the aircraft and asked to locate the airfield using a battery-powered strobe (Figure 1) placed approximately 1 mile north of the runway. The pilot then overflew the runway, located the wind $T$ and identified the direction it was pointing, and made the appropriate downwind, base, and final low approach. Touch-and-go and full-stop landings were not required. Each pilot filled out a questionnaire and added comments at the end of the test. (a)

The pilot selection criteria were based on having subjects with air taxi qualifications and experience. Thus, pilots were required to have a min imum of $500 \mathrm{~h}$ flying time, an instrument rating, and a commercial rating. Twenty pilots having these qualifications participated, including FAA flight standards personnel, a NASA test pilot, volunteers from the flight service supplying the aircraft, and several local pilots. Locally available Cessna 206 and 172 aircraft were chosen for the tests because they are typical aircraft used for air taxi operations.

\subsection{TEST IMPLEMENTATION}

After considering several sites, a dirt strip near Benton City, Washington, was selected and mutually agreed to by the PNL test director and the FAA test supervisor (Figure 2). The site was chosen because it was:

1) located in a relatively remote area, free from significant concentrations of ambient light sources; 2) located in an open field with the same terrain and fol iage as the area surrounding the test landing surface; and 3) located close to (within approximately 25 miles) the major community from which the subject pilots and aircraft resources could be drawn.

(a) A more detailed discussion of this procedure is presented in Reference 24. 


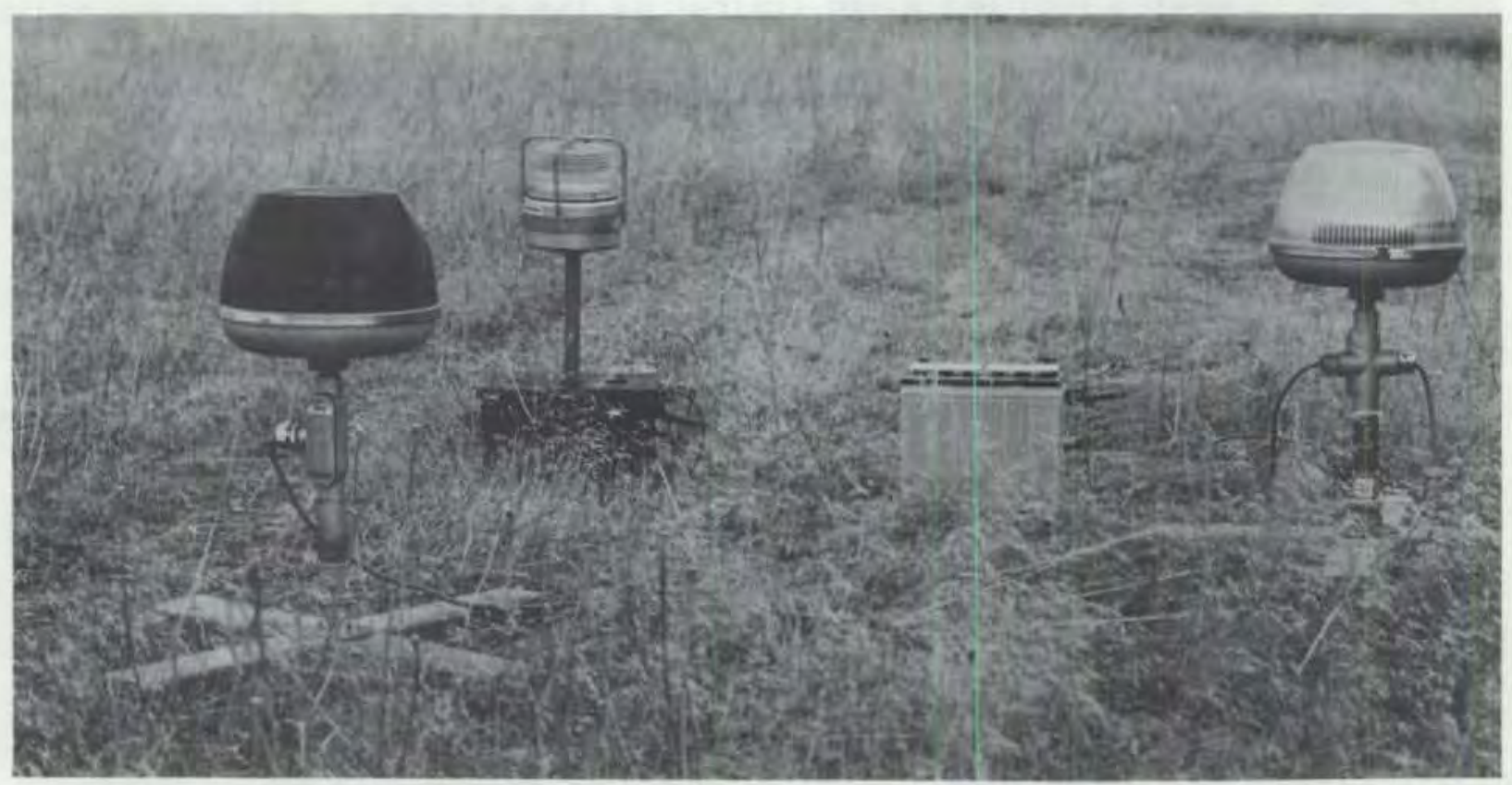

FIGURE 1. Strobes Used for Evaluations Near Benton City, Washington

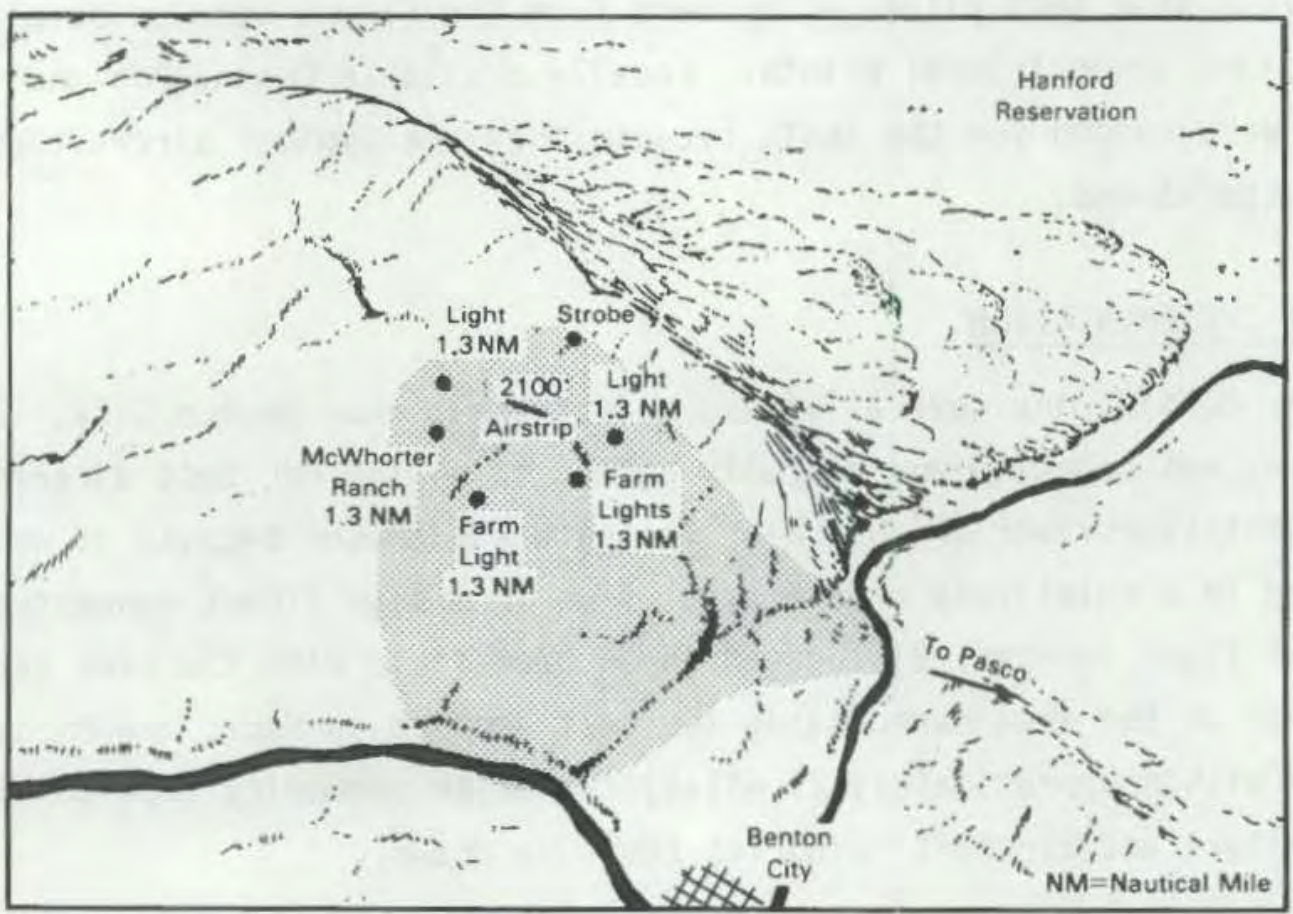

FIGURE 2. Site of Federal Aviation Admin istration Test 
The 2100-ft runway was configured as shown in Figure 3 . Incandescent 1.3-mile markers were placed as needed for distance identification (Figure 2). The runway was shorter and narrower than identified in the FAA test plan; however, the contrast between the landing surface and the surrounding area were such that lights were needed to define the runway. Since touch-and-go and full-stop landings were not permitted, this difference was of minimal concern. Six RL lighting panels using the newer tritium tube design developed by ORNL during $1983^{(1,2,7)}$ were mounted in newly designed edge light support fixtures (Figures 4 and 5 ). This fixture design was evaluated in static tests on the Arid Lands Ecological (ALE) Site on DOE's Hanford reservation and was found to provide superior illumination than those designed for earlier Alaskan testing. $(1-3,8)$ The thresholds were constructed us ing 14 RL light panels mounted in a mixture of the edge light fixtures and those designed and used in Alaska (Figure 6). A lighted wind $T$ (wind direction indicator) consisted of 12 RL light panels mounted horizontally on a T-shaped channel (Figure 7). The

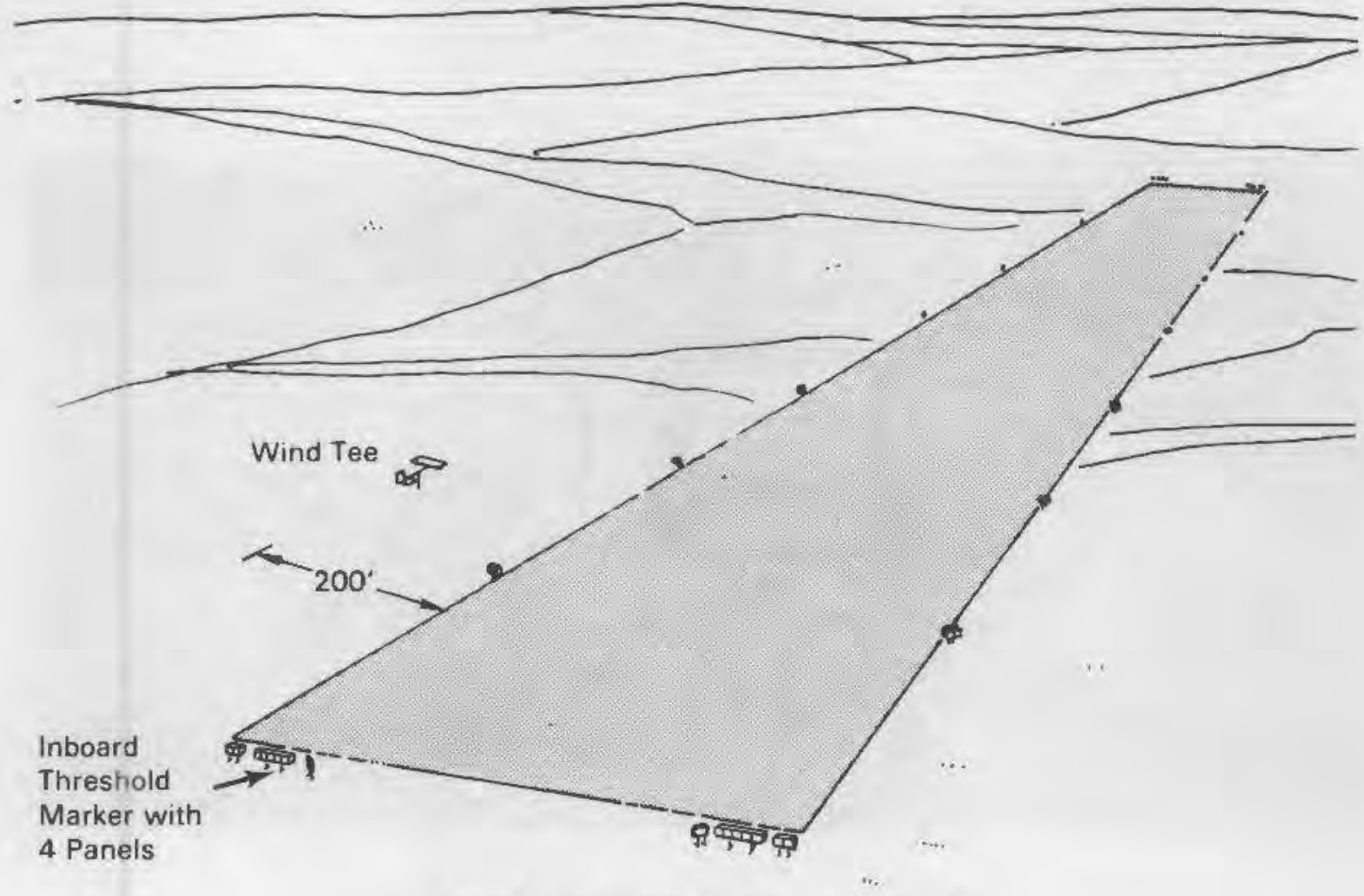

FIGURE 3. Flight Test Runway 


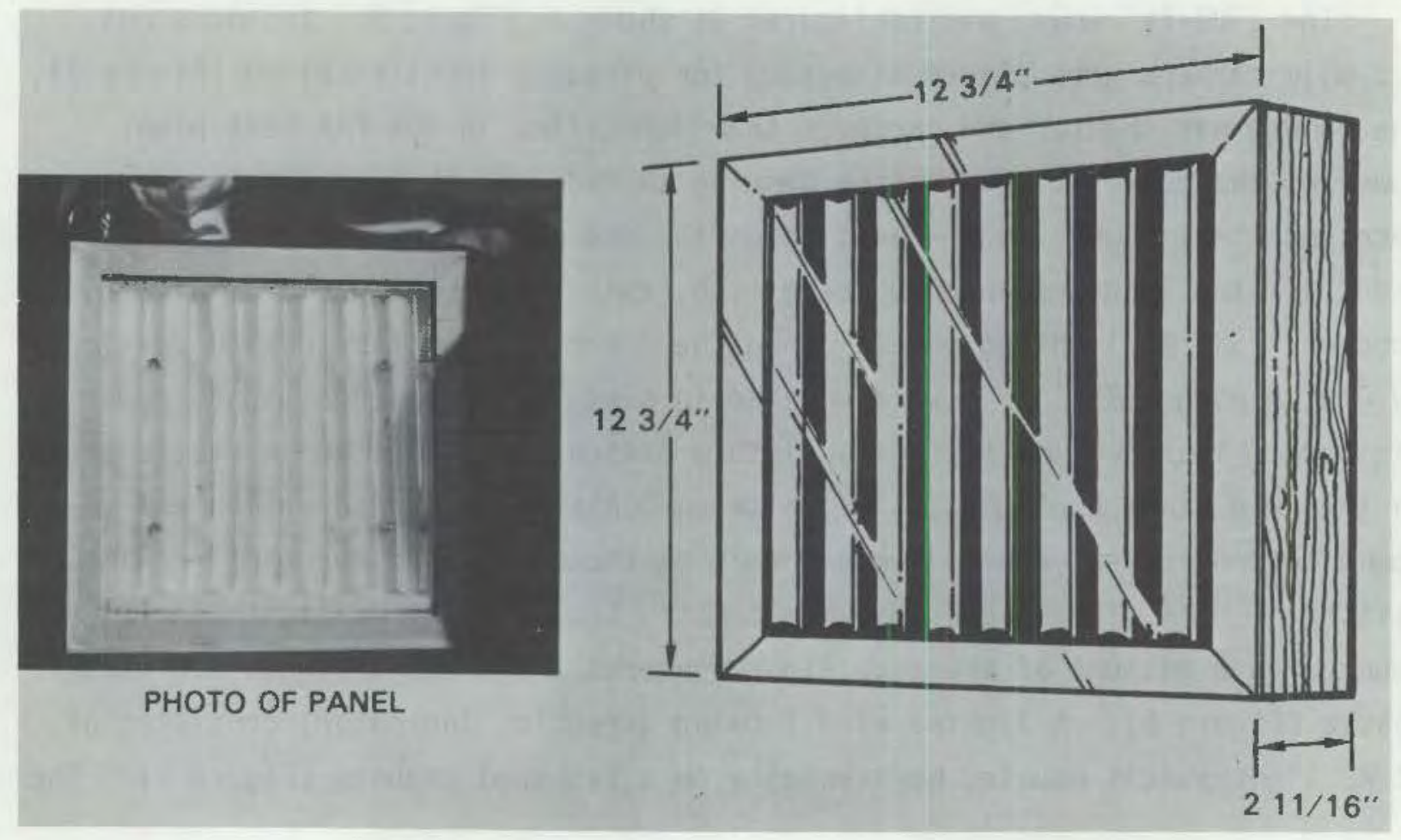

FIGURE 4. Radioluminescent Lighting Panel

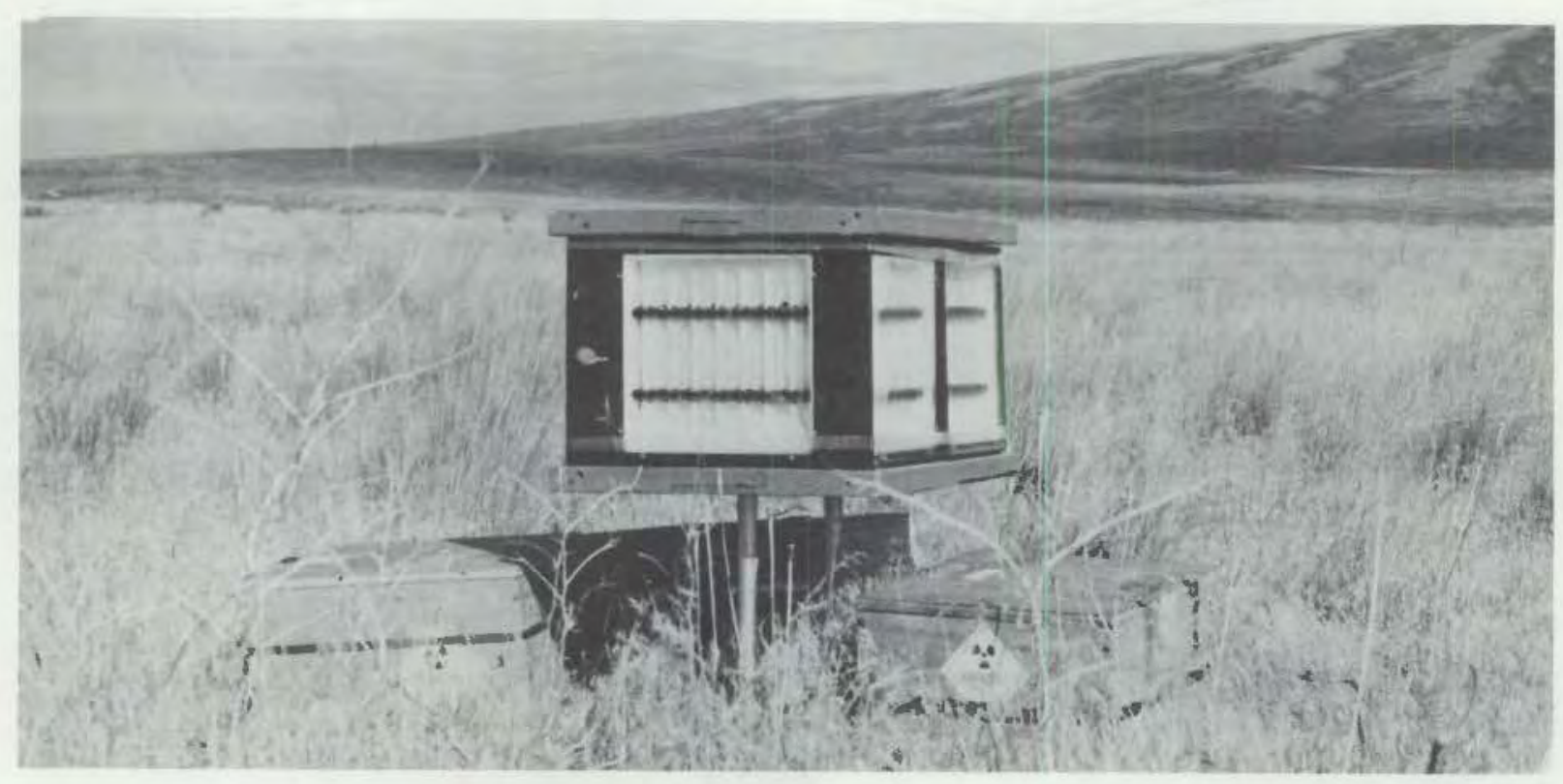

FIGURE 5. Edge Lighting Fixture 


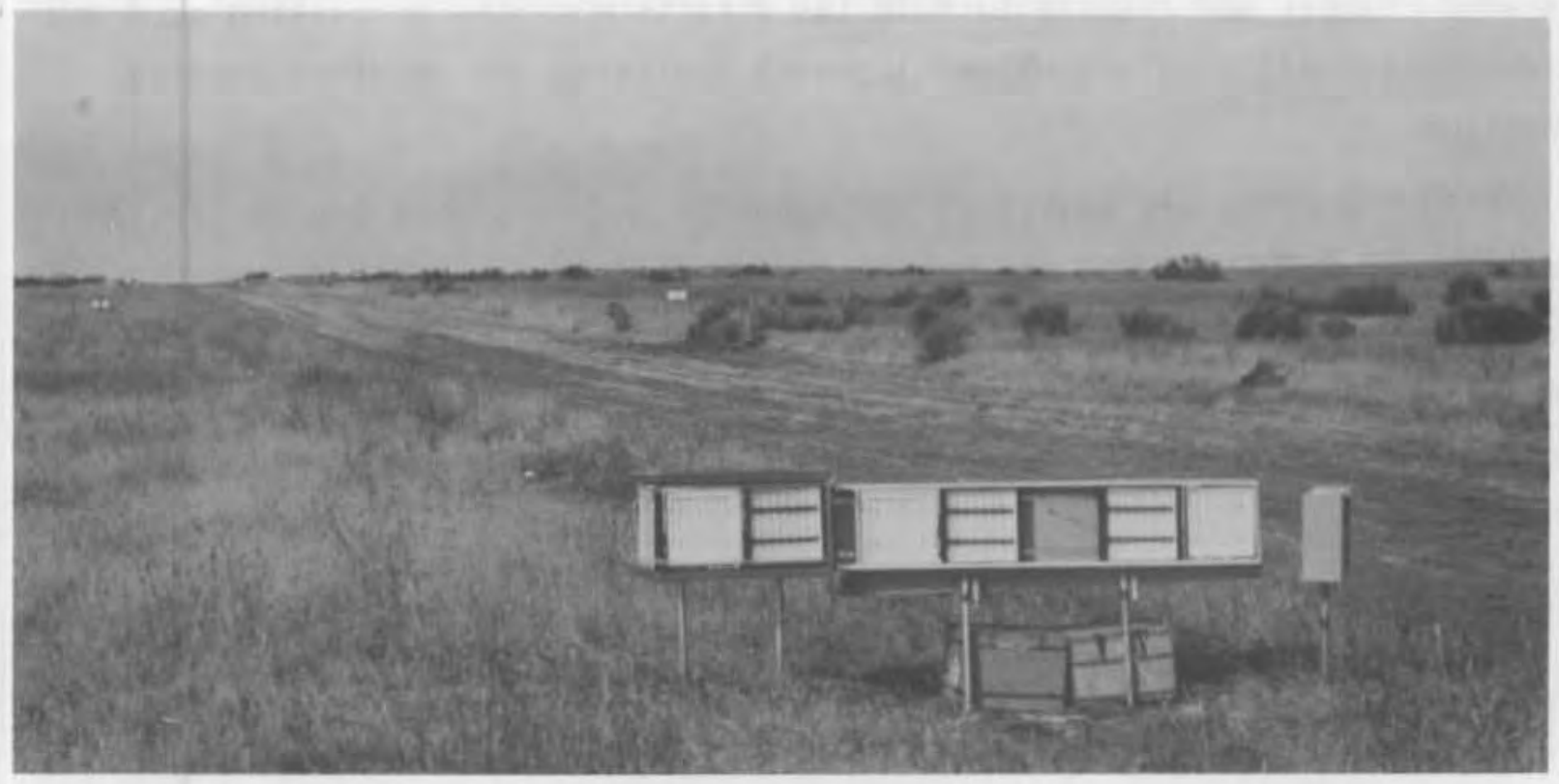

FIGURE 6. Threshold Configuration at East End of Test Runway

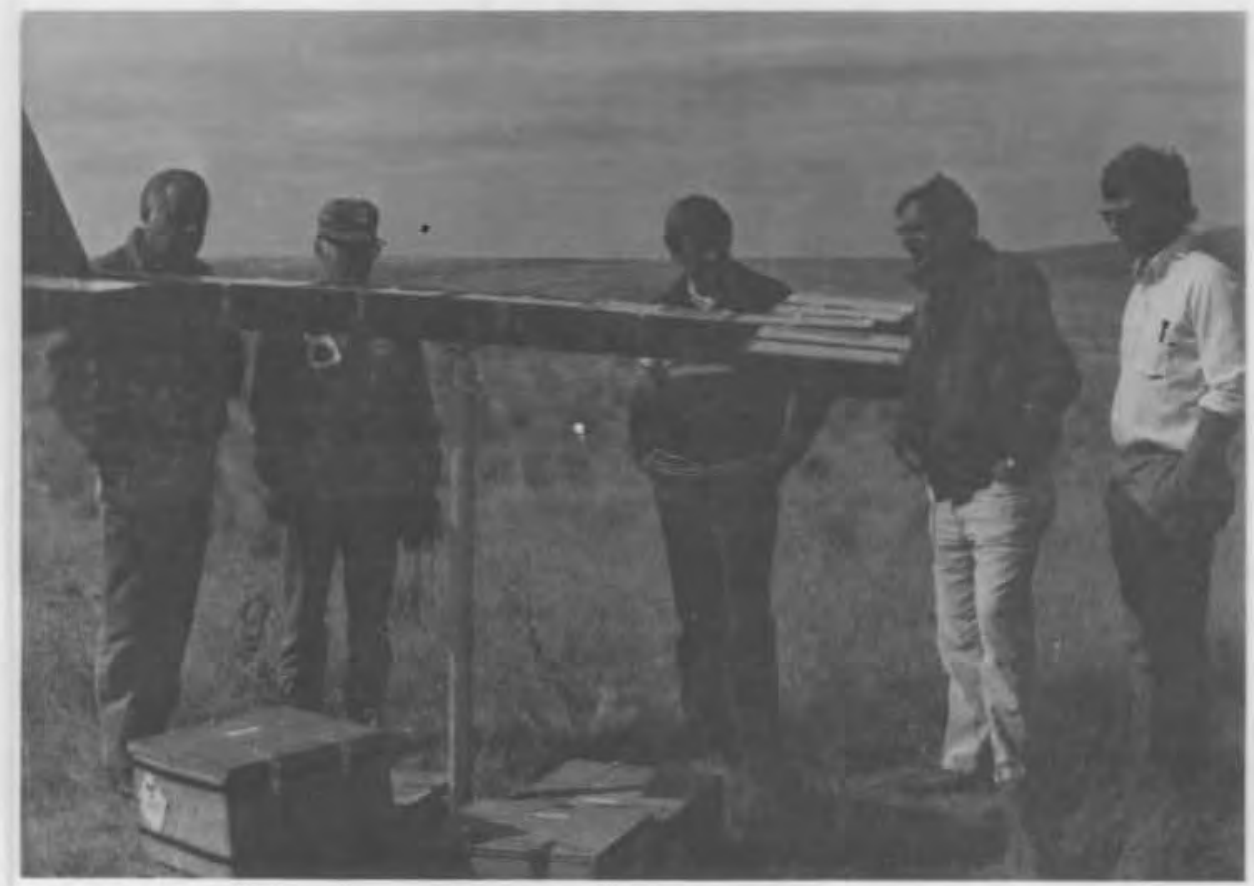

FIGURE 7. RL-Lighted Wind Direction Indicator 
T-shaped channel was free to turn in the direction of the prevailing wind and resembles a small airplane whose alignment indicates the required landing direction.

Flight testing was initiated September 27 and completed October 3, 1984. The night of October 3 was reserved for video and photographic documentation, evaluation of the visual glide slope indicator, and some flight tests to identify maximum acquisition (where the runway could first be seen) distance. The system was then disassembled and returned to ORNL on schedule. 


\subsection{TEST RESULTS AND DISCUSSION}

Additional details of the test results are documented in the FAA report. (24) This section is limited to a brief discussion and summary of the results.

\subsection{TEST RESULTS}

Twenty pilots participated in these tests. Each pilot departed from and returned to the Tri-Cities Airport at $\mathrm{Pasco}$, Washington. Each subject pilot was accompanied by the FAA test supervisor and an FAA observer when the Cessna 172 aircraft was used and by an FAA flight standards pilot, an FAA observer, and others observing the test when the Cessna 206 aircraft was used. The FAA test supervisor and flight standards pilots were also the safety pilots and in command of the aircraft. All subject pilots held at least a commercial category FAA pilot certificate, current medical certificates, and vaiid instrument ratings. In addition, the average experience level of all 20 pilots was 4365 flight hours; minimum pilot experience was 1600 flight hours. All pilots were briefed on the test procedure and the evaluation needs and given an opportunity to view several lights installed on the ramp at the Tri-cities Airport. This procedure was followed to ensure that the pilots understood the test procedure and appreciated the difference in appearance of the RL lights as compared with conventional lights.

Pilot responses to Phase I, II, and III portions of the test are summarized in a sample pilot questionnaire (Figure 8). With one exception, in Phase I, all pilots correctly identified their location relative to the airfield. The one pilot corrected his initial call after noting his correct position. In Phase $I I$, all pilots said they had no difficulty maintaining visual contact and guidance with the runway on the downwind and base of the approach at a minimum of 1.3 nautical miles away from the runway. One pilot reported that the RL system only marginaliy defined the runway outline to permit proper alignment and guide path on final approach but commented that it "may take a little time to get used to dimmer lights." All other pilots responded to Phase II Question 3 affirmatively, indicating that they experienced no difficulty in maintaining proper glide path and alignment with the 


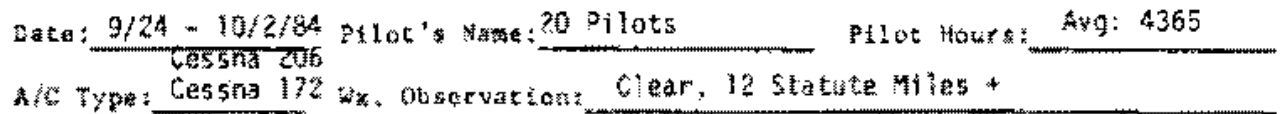

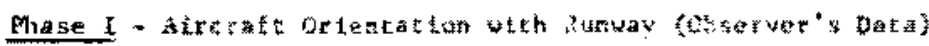

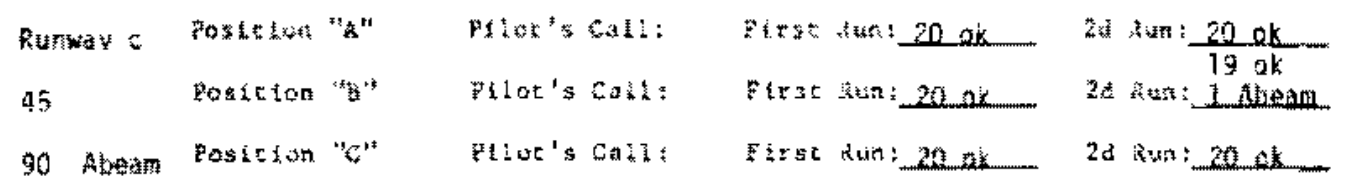

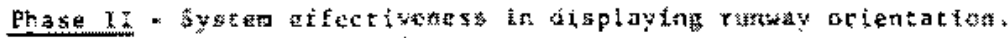
(

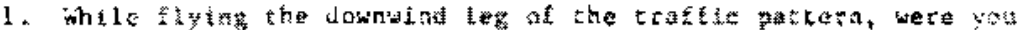
abla 5 a

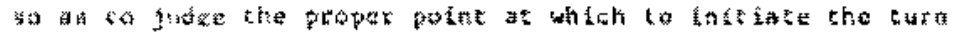

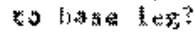

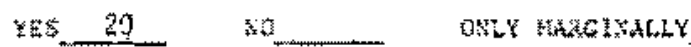

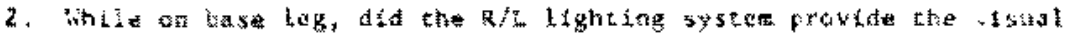
runaty als

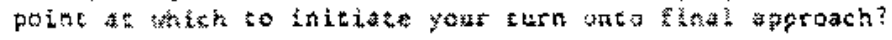

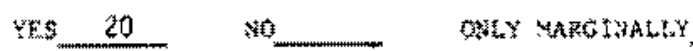

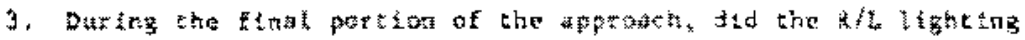

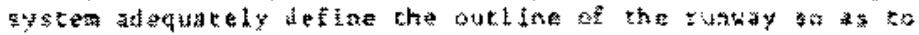

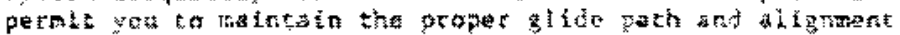

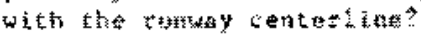

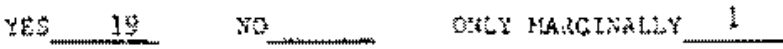

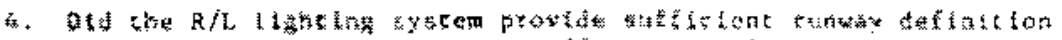

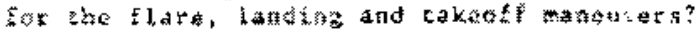
$Y E S \quad 1+\frac{1}{3}$
An

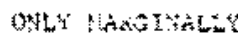

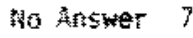
Coted
Sof

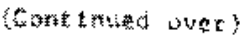

FIGURE 8. Pilot questionnaire and Data Sheet 


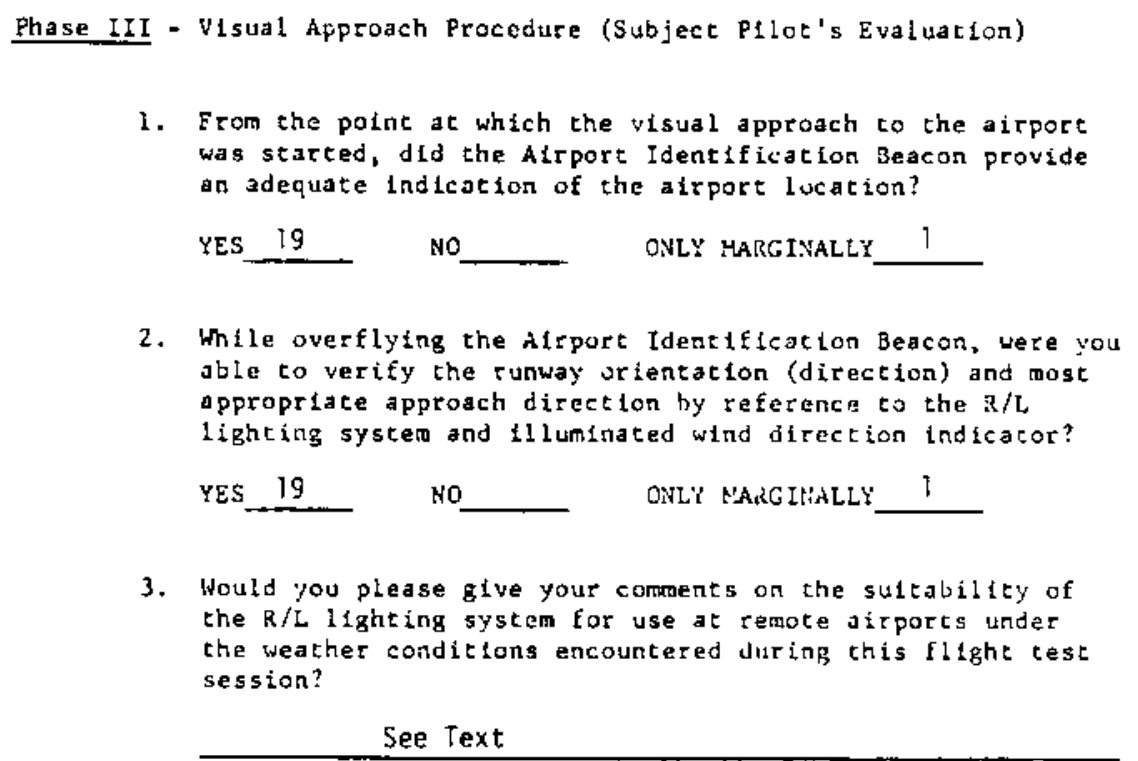

ItLANK YOU:

FIGURE 8. (Continued)

runway centerline during the final approach. The responses to the Phase III questions were similar to Phase II. No problems were experienced in locating the airstrip and maneuvering to a final approach. One pilot rated the strobe beacon as marginal but stated that it "could be located closer to the runway (otherwise, yes)." However, all pilots could identify the strobe beacon during their approach to the test site as they passed Richland, 14 statute miles from the site. All pilots indicated in their comments or responses that they bel ieved they could have safely landed; 13 pilots answered "yes" to 
Phase II Question 4, 5 pilots responded "N/A," and 2 chose not to respond. Several pilots indicated that they were "high" or the runway seemed further away on final approach than it really was. All commented that once they became used to the system, this would not present a problem. All pilots correctly Identified the landing direction as indicated by the wind $T$. Ground personnel randomly aligned the wind $T$ for either a west or east approach. Several pilots expressed that "they needed to be directly over the whit $T$ or it was not definitive."

In order to identrify usable acquisition distance, the safety pilot requested that the subject pilots unistakly identify the runway outline as defined by the $\mathrm{R}_{\mathrm{L}}$ system. This determation was made whe making approaches at $a 5^{\circ}$ angle to the runway and ranged from 1.5 nautical miles on bright moonlit nights to 2.0 nautical miles when the moon was dark. Comments and concerns that the subject pilots expressed on the questionnaires are found in Table 1 . The statements reflect the general nature of the written comments but are not exact quotations. The number of pllots expressing a concern or comment is also show. Pilot comments or concerns were also recorded by the FAA observer in the alroraft, $(24)$

Weather conditions during the test period were at least 12 miles visibility and, with two exceptions, clear. The two exceptions were september 29, when there was ath in overcast and some haze, and September 30, when the over" cast was gone but the haze pers is ted. However, Pasco, Washington, 23 miles away, was still visible. The moon becane a factor on september 29 when it reached $3 / 8$ moon; it reached $2 / 3$ moon by the end of the test period. Thus, fin this test, we were not able to evaluate the fl lights ander the minimum speci... fied criteria (wth a minimum prevaling visiblitity of 2 to 3 statute miles). Some pllots and observers reported wisual contact (a) with the runwy at 3 to 3.5 mies along the rutway centerline and 2 to 2.3 inles at a $90^{\circ}$ angle (abeam) from the runwy direction. In one case, U.S. Army personnel in a UH- I helicopter visiting the test site reported visual contact with the runwa ower Benton $c_{\text {ity }} 5$ miles away from the state.

(a) Visual contact or acaulstion is defined as wher an individual first sees a glow from the RL systen. 
TABLE 1. Pilot Concerns or Coments

Pilots Responding

System was satisfactory in the weather conditions flown

Anticipated no problens with completing the landing

9

Use of landing lights on final approach reduces the

effectiveness of the RL lighting system

There is a need for more testing in marginat VFR weather ( 2 to 3 miles wistibillty)

Must fly drectly over the lighted wind direction

indicator to use it effectively

Airport identiflcation beacon essential for finding

runway arport location

A visual approach slope indicator would be nost helpfus:

Windshield glare, due to instrument refiections, can

cause temporary loss of guidance

4

High on final glide slope due to relatively low intensity

of RL lighting system and "black hole" effect

$2-3$

Lights harder to see on downind than on base or final approach

Testing should include landings to full stop 2

Special training will probably be required for user

Higher level of anblent light could present problems

Wind difection indicator too close to runwa lights 2

Moonlight decreases efrectiveness of RL lighting system 2

Anticipated no problens with taking off 


\subsection{DISCUSSION}

All pilots could identify, maintain contact with, and use the runway from 1.5 miles or greater during approach; and most felt they could have landed. In addition, pilots reported that they could use the lights for runway alignment from distances of 2 miles under very dark clear conditions and between 1.5 and 2 miles under $3 / 8$ to $2 / 3$ monlight and hazy conditions. Some pilots and observers reported $v$ isual contact with the runway at 3 to 3.5 miles along the extended runway centerline and 2 to 2.5 miles when $90^{\circ}$ from the runway direction. Visual contact was measured during approaches from east to west or while flying parallel to and south of the runway centerline. Other points include:

- The use of extra edge lights may be more effective than increasing the light emission from the threshold area.

- A navigational aid, such as a strobe light, is needed to lead civilian pilots to the airfield. Once the pilot is in the vicinity of the airfield, the RL lights are a good landing aid.

- FAA flight standards pilots evaluating the lights felt that they courd be used for Part 135 FAR operation.

- The lights worked well under the weather conditions of the tests.

- A visual glide slope indicator was requested by pilots.

- Pilot vision and/or training may be an important factor and may account for the variation in visual contact, usable acquisition distances, and the high approach reported by several pilots.

- Improvement in the wind direction indicator was requested by pilots. 


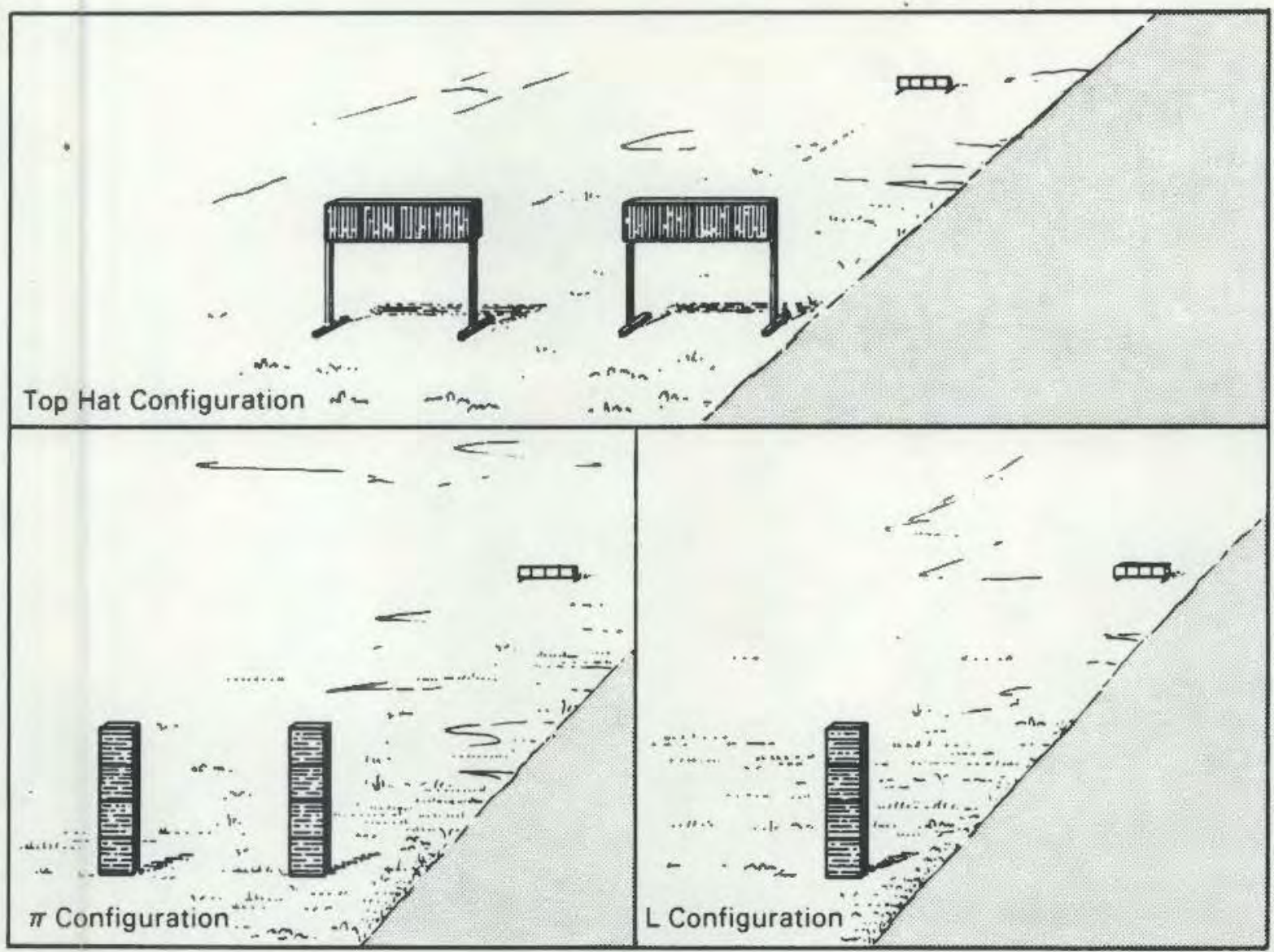

FIGURE 9. Possible Visual Glide Slope Indicators 


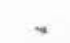

, 


\subsection{RECOMMENDATIONS}

The following recommendations resulted from the data and other information obtained during this test and evaluation. Additional recomendations and program needs have been identified alsewhere $(1,3,7,8)$ and will only be repeated here when pertinent or were clariftcation is required:

- Although the RL lights worked well under the atmospheric conditions encountered during the test, more flight testing will probably be needed under other weather conditions that approach the mininum VFe criteria of 2 to 3 miles visibility (fog, rain, snow, etc.) before unqualified FAA approvals under $P$ arts 135 and 91 FAR are given.

- To accomplish the above, a rural RL-lighted runway is needed for further testing to take advantage of local minimal visibility conditions when they exist. This runway could be in Alaska, near Richland, Washington, or at another location in the contiguous 48 states. The runway should be located close to a major airport facility having appropriate instrument navigational aids to allow the test aircraft to go to and from the test site. However, it needs to be far enough away from cities or towns so that ambient light is not a significant factor.

- Further development and evaluations of candidate visuat glide slope indicators are needed (Figure 91. Previous evaluations ${ }^{(8)}$ have shown that the top hat configuration is of minimal value, but an L-shaped configuration has shown promise (Figure 9). Further work in this area is needed.

- The intensity of the lights needs to be increased as much as possible. Better phosphors, enhanced reflector designs, and nore efficient tube designs are a 11 needed.

- The wind direction indicator should be improved. The bas ic design appears reasonable, but the intensity of the light output needs to be increased. 
effort should be done in a static mode prior to flight testing to ensure that a knowledge bese for using the light produced is established.

- The human factors evaluation should be accompan ied by instrumental measurements to ensure that the human factors yersus physical relationship is identified. These comparative data may be useful to designers who have to extrapolate to other meteorological conditions and provide suitable parameters for engineering designs for different locations and clinates.

- The test criterla and procedure developed for this test worked well and shonld be used as a model for further testing involving Catetory $A$ or higher performance aircraft. 


\section{REFERENCES}

1. Jensen, G. A., et al. 1984. Examination of the Feasibility for Demonstration and Use of Radio tuminescent Lights for A]ask an Remo te Runway Lighting. PNL-5183, AK-RD-84-16, Pacific Nor thwest Laboratory, Richland, washington.

2. Haff, K. W., J. A. Tompk ins, and F. N. Case. 1983. Evaluation of Arctic Test of Tritium Radioluminescent Lighting. ESL-TR-82-35, 0ak Ridge National Laboratory, Oak Ridge, Tennessee.

3. Leonard, L. E. 1984. Radioluminescent Lighting Applications in Alaska. State of Alaska, Department of Transportaton and Public Facilities, Division of Planning/Research Section, Fairbanks, Alaska.

4. Case, F. N., and K. W. Haff. 1981. Krypton-85 Powered Lights for Airfield Application. AFESC/ESL-TR-80-55, prepared for Air Force Engineering and Services Center, Tyndall AFB, Fiorida, by Operations Division, Oak Ridge National Laboratory, Oak Ridge, Tennessee.

5. Haff, K. W., et al. 1981. Testing of Tritium-Powered Runway Distance and Taxiway Markers. ESL-RT-81-45, prepared for Air Force Engineering and Services Center, Tyndall AFB, Florida, by Dperations Division, Oak Ridge National Laboratory, Oak Ridge, Tennessee.

6. Case, F. N., W. C. Remini, and R. E. Nelson. 1982. "Current Development in Radionuclide Light Production." Trans. ANS 43:89-90.

7. Oak Ridge National Laboratory. 1984. "Tritium Radioluminescent Lighting Development." Presented at Technology Transfer Conference, March 21-22, 1984, Oak Ridge, Tennessee.

8. Jensen, G. A., and L. E. Leonard. 1984. Radioluminescent Lighting for Alask an Runway Lighting and Marking. PNL-5328, Pacific Northwest Laboratory, Richland, Washington.

9. Ikeda, M., T. Yanagi, and Y. Shinozaki. 1966. "Measurement of Leakage Tritium from Tritium Self-Luminous Paints." Radioisotopes, Metropol. I sotope Research Center, Tokyo, Japan, 19-22.

10. Wilson, E. J., and J.D.H. Hughes. 1960. "Light Sources Using Radioisotopes." Contemporary Phys. 1(1):62-69.

11. "AEC Exempts Tritium and Promethium and Increases Tritium Limit." I sotopes and Radiation Technology 4(3):306, 1967.

12. Niemeyer, R. G. 1970. "Tritium Loss from Tritium Self-Luminous Aircraft Exit Signs." Isotopes and Radiation Technology 7(3):349-352. 
13. Korin, A* and M. Givon. 1975. "Paraneters Aftacting the intenstity of Light Sources Powered by Trtitum." Nuclear Instruments and Methods $130(2): 23 \div-237$.

14. Ristango, C. V., et al. 1978. "Use of Tritüum Luminous Sources for Lughting Digital Wristwatches Radioactivity in Consumer Products." Micro Display Systems, Inc.s Dallas, Texas, for Nuctear Regulatory Commatsion, washington, D.C., pp. 320-322.

15. Niemeyer, R. G. 1969. Tritum Loss from Tritum Self-Luminous Airoraft Exit 5igns. ORL-TM-2539, Oak Ridge National Laboratory, Oak Rldge; Tennessee.

16. Schoolsy, L. C., and A. A, Regan, 1980. "Visibllity and Legibility of Exit Signs. Part I: Analytical Prediction." Illumirating Engineering Society, October 1980, pp* 24-28.

17. Schoolsy, L. C., and J. A. Regan, 1980. "Visibility and Legibility of Exit Signs. Part II: Experinental Results." Illuminating Engineering Society, October 1980, pp. 24-28.

18. Zielentach, W. J. 1978. Studies of Beneficlal Energy Applications for Krypton-85, Task 83 . FinalReport, BMl-X-697, BatteTle Columbus Laboratories, Columbus, of 10, p. 97.

19. Dix, 6. P. 1979. "Recycle Nuclear Waste: Why Not." Energy 4(1):23-24.

20. Case, F. N, and $W_{*}$ C. Reminis 1980. "Radioisotope Powered Light Sources." Presented at Airport !ighting Soctety of North American Meting, Noventer 1980.

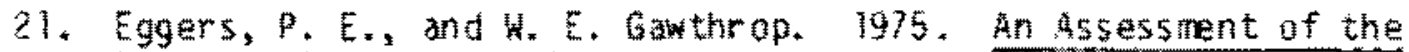
Potentally Beneficlal Uses of Krypton-85, Find Report, Task 6x. BM: $X-660$, BatterTe Columbus Labor atories, Columbus, oh io.

22. Tingey, G. L., et al. 1983. "Potential for Beneficial Use of Krypton-85." PNL-SA-10832, presented at Was te Managerent Conference, February 27, 1983, Tucson, Arizona.

23. Moghissi, $A_{*} A_{2}$ and $M_{*} W_{*}$ Carter. 1975, muolic health Implicatons of Radloluminous Materials." U.S. Department of Health. Education, and welfare, Food and Orug Atministration, Rockvllla, Maryland.

24. Paprocki, T. H. 1984. Evaluation of Radio-Luninescent Lighting System. OOT/FAR/CT-TN84/49, U.5. Department of Transportation, Federai Aviation Administration, At 1 antic City, New Jersey.

25. National Transportation Safety Board. 1980. Special Study: Air Taxi Safety in Alaska. NTSB-AAS- $80-3$, Washington, D.C. 


\section{DISTRIBUTION}

No. of

Copies

OFF SITE

$2 \quad L * E *$ Leonard

state of Alask a DoTspF

2361 Peger Road

Farbanks, AK 9970 a

L.. Hegdat

State of Alask a OOTSPF

2361 Peger Road

Fairbanks, AK 99708

W. C. Remini

Rav and Byproducts

U. . Department of Energy

Washington, DC 20545

J. J. Jicha, Jr.

Rol and Byproducts

U. S. Department of Energy

Wash ington, DC 20545

27 DOE Technical Informatuon Center

K. W. Haff

P.0. Box 芙

Oak Ridge National Laboratory

ouk Ridge. TN 37830

E. Lanb

P.0. Box X

Oak Ridge National Laboratory

Oak Ridge, in 37930
No. of

Copies

DNSITE

4 DOE Richland Operations office

M. Dayani

H. E. Ransom

1. L. Rhoddes

J. D. White

2 Battelle Alaska Operations

L. D. Perrigo

40 Paciftc Nor thwest Laboratory

5. K. Edler

C. R. Hann

P. E. Hart

ป. H. Jarrett

G. A. Jensen (26)

U. L. MCElroy

A. M. Platt

G. L. Tingey

Publisning Coordination (2)

Technical Information (5) 
